\title{
THE IMPACT OF DIGITAL INFRASTRUCTURES AND TRANSPORTATION SERVICES ON ECONOMIC GROWTH: RECENT EVIDENCE FROM HIGH-, MIDDLE- AND LOW- INCOME COUNTRIES
}

\author{
Haifa MEFTEH \\ Faculty of Economics and Management of Sfax, Sfax,Tunisia \\ meftehhaifa1@gmail.com
}

\begin{abstract}
This study investigates the links between digital infrastructures (DI); transportation services (TS) and economic growth using simultaneous-equation panel data models for a panel of 62 countries for the period 2000-2018.

The results indicate that there is evidence of bidirectional relationship between $D I$ and economic process. Economic growth and TS are interrelated bidirectional relationship. Bidirectional link is validated between DI and TS for high-income and middle-income countries. Unidirectional causality is running from TS to DI for low incomes countries. These empirical insights are of particular interest to policymakers, working in low incomes countries. They help them to develop modern DI and TS to sustain economic development and to push substantial changes within the way of life and productivity. This has led to enormous technological advancement which is in line with but at a faster pace than the technological advancement of previous revolutions.
\end{abstract}

Keywords: Digital infrastructure. Transportation services. Economic growth. GMM.

JEL Classification: A10, C31, L86, L91

\section{Introduction}

The new economy as opposed to the old one is based essentially on the technologies as one of the main components to support the economic development (Jorgenson and $\mathrm{Vu}$, 2016; Niebel, 2018; Romer, 1990; Saidi and Mefteh, 2020). Moreover, Hong (2007) argue that ICT affects positively the FDI attractiveness by improving traffic volume, reducing travel times and costs. Additionally, Cardona et al. (2013); Paunov and Rollo, (2016) indicated that digitalisation benefits economic growth by facilitating transactions, production innovations and network externalities. In relation to the main reasons for additional recent studies on the relationship between digital infrastructures and economic growth including other important variables, such as human capital (Aleksandra and Joan, 2017). Similarly, some others studies have incorporated transportation services into production function to investigate the relationship between economic growth and digital infrastructures.

The automotive of 2020 , reduced from digital economy would have the ways of defining and realizing the journeys, through communicating, for optimal security, with the infrastructure. It is to be noted that no study worth noting that has been concluded that analyzed the ICT development role in transport and economic development. Moreover, as we know so far,

Cite as:

Mefteh, H., 2021. The Impact of Digital Infrastructures and Transportation Services on Economic Growth: Recent Evidence from High-, Middle- And Low-Income Countries. Oradea Journal of Business and Economics, 6(2), pp. 29- 42. http://doi.org/10.47535/1991ojbe127 
there have not been any empirical studies focusing on examining the causal associations between digital infrastructures and growth through the cointegration model.

Our study is different from the previous studies in three ways. (i) To the best of our knowledge, none of the previous studies have estimated the three-way linkages between digital infrastructures, transportation services and economic growth. For this reason, we found great motivation to integrate a first approach to investigate the three-way linkages between these variables. (ii) The empirical investigation concerns 62 countries with different income levels and divided into three sub-groups, namely; high-income, middle-income, and low-income countries. (iii) We use the Generalized Method of Moments for the dynamic panel data model following the three sub-panels. The present paper starts by an introduction followed by a literature review. In section three, we have the methodological framework and we present the obtained results and discussions. Finally, the conclusion and policy implications are given in section four.

\section{Theoretical framework}

Numerous researchers' studies argued that the application of telecommunication infrastructures promotes the effectiveness of production at a global level (Garbacz; 2011). Similarly, Jorgenson and $\mathrm{Vu}$ (2007) disclosed a straight link between economic growth and ICT for 110 countries, counting the USA. Roller and Waverman (2001) identified a positive linkage between ICTs infrastructures and economic growth for a panel of 21 OECD countries between 1970 and 1990. Seo et al. (2009) settled that investment in digital infrastructures affects GDP growth positively for 29 countries along with Venturini (2009) for the USA and 15 EU countries Oulton (2012) for the United Kingdom; Daveri (2002) for economies of European Union; Kumar and Kumar (2012) for Fiji; Kuppusamy et al. (2009) for Malaysia. In the same vein, $\mathrm{Vu}$ (2013) explored the effect of ICT on the economic development of Singapore and resulted that ICTs contributed by $1 \%$ to Singapore's economic growth between 1990 and 2008.

Lee and Khatri (2003) examined the impact of ICT on economic development of South Asian countries. They introduced the non-ICT capital, ICT capital (including hardware, software and communications) and labor force as independent variables. The study made use of ICT expenditure data provided by WITSA 1 for the periods of 1990-94 and 1995-99. The main results showed that ICT's influence economic development stems from capital deepening effect of the ICT sector in 1990s. Matambalya and Wolf (2001) used the data form 150 companies between 1999 and 2000 to investigate the causal relationship among ICT and economic development in Kenya and Tanzania. In the empirical study, the authors included non-ICT capital, ICT, productivity and labor force as explanatory variables. In the conclusion, Matambalya and Wolf (2001) argued that the economic growth was significantly and positively affected by the ICT.

Khadaroo and Seetanah (2008) investigated the impact of transport infrastructures on economic growth in the case of Mauritius during the 1950-2000. In addition, Shan et al. (2014) investigated the economic impact of seaports on host city's economic development in China from 2003 to 2010. Based on data from 41 major port cities, they found that port cargo throughput considerably contributed to the economic growth of the Chinese host city. Correspondingly, Park and Seo (2016) investigated the positive influence of port infrastructure on Korean economic development from 2000 to 2013 . They asserted that actually cargo ports contribute chiefly to regional economic development when they having sufficient throughputs. For multinational companies, transport infrastructure has been perceived to be a consequential intermediate input in private production process, which could directly influence their competitiveness. For multinational companies, a smart transport system is critical to advance their logistics functions, and smooth investments 
overseas. Many studies nowadays, have established the considerable economic worth of logistics. They contend that logistics itself is becoming a novel industry that contributes significantly in the economic progress of nations. To examine the impact of transport on economic growth for China from 1980 to 2009, Lean et al. (2014) used dynamic structural models. The authors found a positive and bidirectional relation in the long run. Several researches have studied the economic role of transport infrastructures, and emphasized their positive influence to economic development, in both developing and developed countries; Khadaroo and Seetanah (2008) for Mauritius; Park and Seo (2016) for Korea; Shan et al. (2014) for China. They conclude that transportation affects the effectiveness of private businesses, and significantly controls their competitiveness. Additionally, they argue that transportation has anpositif effect on FDI attractiveness, thus stimulating fiscal development of host countries.

Moreover, several additional studies have tried to inspect the causal connection between digital infrastructure and logistics functions. Crowley (1998) established the positive linkage between digital infrastructures, transport and logistics services in a global supply chain. The author added that third-party logistics (3PLs) could in fact use digital infrastructure to convert a supply chain configuration. Recently, Saidi and Mefteh (2020) examined the relationship between information and communication technologies (ICT) and transport in 63 countries with different income levels. Their results confirm the positive role of transport and ICTs in supporting economic growth by strengthening countries' economic openness and increasing their participation in international trade.

As conclusion, the intelligent transport system is a new economic factor that needs both elaborate theoretical and empirical studies. Several authors have fleetingly conversed on the increasing role of advanced ICT tools in improving the productivity of transportation systems and logistics functions. However, to our limited knowledge, no researches in the past have looked to study a three-way relationship among digital infrastructures, transportation services and economic growth. Our major contribution to the existing literature would be by exploratory the different linkages between the three variables with examined to their impacts on economic growth in different income countries.

\section{Methodology and data}

\subsection{Model Specification}

Therefore, the main objective of this paper is to examine the three-way linkages between digital infrastructures, transportation services and economic growth in 62 countries. We used a Cobb-Douglas production function where by the gross domestic product (GDP) depends on capital and labour force. The gross domestic product (GDP) depends on endogenous variables including digital infrastructures (DI), transportation services (TS), labor force (L), foreign direct investment (FDI), capital stock (K), human capital (HK) and trade openness (TO). The general production function is modelled as follows:

$Y_{t}=f\left(D I, T S_{t}, H K_{t}, F D I_{t}, T O_{t}, K_{t}, L_{t}\right)$

Where, economic growth $\left(Y_{t}\right)$ is a function of digital infrastructure (DIt), transportation services (TSt), human capital ( $\mathrm{HKt})$, foreign direct investment inflows $\left(F D I_{t}\right)$, trade openness (TOt), capital stock $\left(K_{t}\right)$ and labor force $\left(L_{t}\right)$. We use the log-transformation of variables and we write equation 1 with a time series specification, as follows:

$$
\begin{aligned}
\ln Y_{t}= & \alpha_{0}+\alpha_{1} \ln D I_{t}+\alpha_{2} \ln T S_{t}+\alpha_{3} \ln F D I_{t}+\alpha_{4} \ln T O_{t}+\alpha_{5} \ln K_{t}+\alpha_{6} \ln H K_{t}+ \\
& \alpha_{7} \ln L t+\mu_{i, t}
\end{aligned}
$$


where, $\ln Y_{t}$ represents natural-log of per capita GDP, $\ln D I_{t}$ is natural log of digital infrastructures, $\ln T S_{t}$ shows natural-log of transportation services, $\ln F D I_{T}$ is natural-log of foreign direct investment inflows, $\ln T O_{t}$ represents natural-log of trade openness, $\ln K_{t}$ represents natural-log of capital stock, $\ln H K_{t}$ indicates natural-log of human capitalln $L_{t}$ andrepresents the natural-log of labor force.

In Equation 2, we also have aik representing the estimated coefficients of all independent variables where $k=1 \ldots 7$. The subscript $i=1 \ldots 62$ denotes the country. The subscript $t=$ $1 . .19$ denotes the time period (2000-2018). Finally, equation 2 contains $\alpha 0$ and cit indicating constant and classical error term respectively.

There is a panel study, which allows us to write equation 2 in panel data form as follows:

$\ln Y_{t, i}=\alpha_{0}+\alpha_{1, i} \ln D I_{t}+\alpha_{2, i} \ln T S_{t}+\alpha_{3, i} \ln F D I_{t}+\alpha_{4, i} \ln T O_{t}+\alpha_{5, i} \ln K_{t}+\alpha_{6, i} \ln H K_{t}+$ $\alpha_{7, i} n L_{t}+\mu_{i, t}$

Keeping effect of labor force in production function and divide the equation 3 by total population, we convert all the variables into per capita units. Equation 3 can be rewritten as follows:

$\ln Y_{t, i}=\alpha_{0}+\alpha_{1, i} \ln D I_{t}+\alpha_{2, i} \ln T S_{t}+\alpha_{3, i} \ln F D I_{t}+\alpha_{4, i} \ln T O_{t}+\alpha_{5, i} \ln K_{t}+\alpha_{6, i} \ln H K_{t}+$ $\mu_{i, t}$

Based on prior studies (Shahbaz et al. 2015, Omri et al. 2015, Omri and Kahouli 2014, Sy et al. 2009, Saidi et al. 2020), we use equation 4 to derive the empirical models to simultaneously treat inter-relationships between economic growth, digital infrastructuresand transportation services. In these models, we have introduced urbanization $\left({ }^{{ }_{t}}\right)$, financial development (FDt) and energy consumption ( ${ }^{E_{t}}$ ), as explanatory variables. The three-way links among growth-digital infrastructures-transportation services are examined by making use of the following three equations:

$$
\begin{aligned}
\ln Y_{t, i}= & \alpha_{0}+\alpha_{1, i} \ln D I_{t}+\alpha_{2, i} \ln T S_{t}+\alpha_{3, i} \ln F D I_{t}+\alpha_{4, i} \ln T O_{t}+\alpha_{5, i} \ln K_{t}+\alpha_{6, i} \ln H K_{t} \mu_{i, t} \\
\ln T S_{t, i}= & \delta_{0}+\delta_{1, i} \ln Y_{t}+\delta_{2, i} \ln D I_{t}+\delta_{3, i} \ln F D I_{t}+\delta_{4, i} \ln E_{t}+\delta_{5, i} \ln U_{t t}+ \\
& \delta_{7, i} \ln K_{t}+\mu_{i, t} \\
\ln D I_{t, i}= & \delta_{0}+\delta_{1, i} \ln Y_{t}+\delta_{2, i} \ln T S_{t}+\delta_{3, i} \ln H K_{t}+\delta_{4, i} \ln U_{t}+\delta_{5, i} \ln F D_{t}+ \\
& \delta_{6, i} \ln K_{t}+\mu_{i, t}
\end{aligned}
$$

Equation- 5 states that economic growth may be potentially affected by digital infrastructures (DIt), transportation services (TSt), human capital (HKt), foreign direct investment $\left(F D I_{t}\right)$, trade openness (TOt) and capital stock $\left(K_{t}\right)$. The majority of previous research studies confirm the positive impact of these variables on economic growth (Achour and Belloumi 2016, Saidi et al. 2020, Saidi et al. 2018).

Equation-6 assumes that transportation services in a country depends significantly on economic growth $\left(Y_{t}\right)$, digital infrastructures (DIt), foreign direct investment inflows $\left(F D I_{t}\right)$, energy consumption $\left(E_{t}\right)$, urbanization $\left(U_{t}\right)$, capital stock $\left(K_{t}\right)$ (Marazzo et al. 2010, Chi 2016, Saidi andHammami 2017). 
Equation-7 postulates that economic growth $\left(Y_{t}\right)$, transportation services $\left(T s_{t}\right)$, human capital $(\mathrm{HKt})$, urbanization $\left(U_{t}\right)$, and capital $\left(K_{t}\right)$ affect significantly the digital infrastructure.

(Solomonand Klyton, 2020, MbarekandZghidi, 2017, Adedoyin, 2020).

In our study, we use dynamic panel data models with simultaneous-equations where lagged values of economic growth, transportation services, and digital infrastructures are taken into account by using the Arellano and Bond (1991) GMM estimator. The empirical models to estimate can be rewritten as follows:

$\ln Y_{i, t}=\alpha_{0} \ln Y_{i, t-1}+\beta_{1} \ln T S_{i, t}+\beta_{2} \ln D I_{i, t}+\sum_{j=1}^{4} \delta_{j} X_{i, t}+\mu_{i, t}+\varepsilon_{i, t}$

(9)

$\ln T S_{i, t}=\eta_{0} \ln T S_{i, t-1}+\lambda_{1} \ln Y_{i, t}+\lambda_{2} \ln D I_{i, t}+\sum_{j=1}^{4} \delta_{j} X_{i, t}+\mu_{i, t}+\varepsilon_{i, t}$

$\ln D I_{i, t}=\ell_{0} \ln D I_{i, t-1}+\gamma_{1} \ln Y_{i, t}+\gamma_{2} \ln T S_{i, t}+\sum_{j=1}^{4} \delta_{j} X_{i, t}+\mu_{i, t}+\varepsilon_{i, t}$

Where InYi,t, InTSi,t, and InDli,t represent respectively, the GDP, the transportation services and digital infrastructures of country $i$ at time $t$. $\alpha 0$ is the parameter to be estimated; $X$ represents the vector of explanatory variables used to model economic growth (digital infrastructures, transportation services, foreign direct investments, trade openness, capital and human capital), to model transportation services (economic growth, digital infrastructures, foreign direct investment, energy consumption, urbanization, financial development, and capital) to digital infrastructures (economic growth, transportation services, human capital, urbanization, capital and financial development). $\mu$ is countryspecific effects; and $\varepsilon$ is the classical error term.

In the first equation, $\beta$ captures the effect of digital infrastructure and transportation services on economic growth. Also, the effect of economic growth and digital infrastructure on transportation services is measured by $\lambda$. Finally, $\gamma$ captures the effect of economic growth and transportation services as explanatory variables on the variability of digital infrastructure as endogenous variable in the third equation.

\subsection{Data}

We identified and selected data from 62 countries based on the availability of data from 2000 to 2018.We use annual data for the per capita GDP (constant 2010 US\$), DI (number of individual using internet \% of population), TS (\% of exports of commercial services), human capital (percentage gross), FDI net inflows (constant 2010 US\$), trade openness (total trade as share of GDP), capital stock (constant 2010 US\$), energy consumption (kg of oil equivalent), urbanization (\% of urban population of total population), and FD (constant 2010 US\$). All the data, collected for the period 2000-2018 are sourced from the World Bank's World Development Indicators (WDI,2020).

\section{Empirical results and analysis}

The global panel (GP) is divided into high, middle, and low-income panels. Twenty-six countries are included in high-income panel, namely, Australia, Belgium, Canada, Chile, Denmark, Finland, France, Germany, Greece, Hong Kong, Hungary, Iceland, Ireland, Italy, Japan, Korea Rep, Luxembourg, Netherlands, New Zealand, Norway, Portugal, Spain, Sweden, Switzerland, United Kingdom, and USA. Twenty-two countries in middle income panel, namely, Albania, Algeria, Argentina, Brazil, Bulgaria, China, Colombia, Croatia, Fiji, 
Gabon, Iran, Jamaica, Lebanon, Malaysia, Mexico, Panama, Paraguay, Peru, Thailand, Turkey, Serbia, and Venezuela. Fourteen countries in low-income panel, namely, Bangladesh, Egypt, Ghana, India, Indonesia, Kenya, Morocco, Nigeria, Pakistan, Sri Lanka, Tunisia, Vietnam, Philippines, and Zambia.In this study, we investigate the relationships among economic aggregates (economic growth, transportation services, and digital infrastructuresin62 countries with different income levels between 2000 and 2018.

\subsection{Descriptive statistics}

The descriptive statistics for all variables used in the empirical investigation are in Table- 1 . These statistics show that all variables are normally distributed since the values of mean and median are close. The skewness negative coefficients indicate that the distribution is skewed to the left, with more observations on the right.

Table1: Descriptive statistics

\begin{tabular}{|c|c|c|c|c|c|c|c|}
\hline & Mean & Median & Maximum & $\underset{\mathrm{m}}{\operatorname{Minimu}}$ & SD & $\begin{array}{c}\text { Skewnes } \\
\text { s }\end{array}$ & $\begin{array}{c}\text { J- } \\
\text { Bera }\end{array}$ \\
\hline $\ln Y_{t}$ & 3566.72 & 3928.74 & 7763.292 & 51.016 & 2967.457 & -0.163 & 4.308 \\
\hline $\ln F D I_{t}$ & 43.369 & 37.853 & 82.652 & 10.096 & 5.736 & -0.770 & 5.141 \\
\hline $\ln T S_{t}$ & 46.295 & 47.322 & 439.703 & 9.351 & 2.969 & 917 & 6.545 \\
\hline $\ln D I_{t}$ & 114.350 & 112.207 & 4320.372 & 19.334 & 5.442 & 1.000 & 3.724 \\
\hline $\ln T O_{t}$ & 378.100 & 326.800 & 409.904 & -53052 & 408.514 & -0.425 & 4.573 \\
\hline $\ln E_{t}$ & 130.928 & 124.991 & 373.743 & 26.005 & 9.930 & -0.931 & 3.750 \\
\hline $\ln U_{t}$ & 223.100 & 207.854 & 630.712 & 0.000 & 213.400 & -0.305 & 3.372 \\
\hline $\ln F D_{t}$ & 245.274 & 240.136 & 180047.38 & 37.983 & 24.696 & -0.540 & 2.582 \\
\hline $\ln K_{t}$ & 118.116 & 113.579 & 54004.661 & -6.286 & 7.504 & -0.652 & 3.473 \\
\hline $\ln H K_{t}$ & 114.350 & 112.207 & 4320.372 & 19.334 & 5.442 & 1.000 & 3.724 \\
\hline
\end{tabular}

Note: SD indicate standard deviation (standard deviation-to-mean ratio), respectively.

\subsection{Panel unit root tests}

In panel data analysis, two-panel unit root tests are appliedto determine the stationary of variables; the Levin et al. (LCC, 2002) and Im and Pesaran (IPS, 2003). However, these tests identify the stationary of the relevant variables. According to Levin et al. (2002) and Im and Pesaran (2003) the variables are non-stationary, whereas the alternative hypothesis states that the variables are stationary. The level of $p$-value determines the acceptance or rejection of $\mathrm{H} 0$. When associating the $\mathrm{p}$-value to the threshold level of $10 \%$, we admit $\mathrm{H}_{0}$ if the $p$-value is greater $10 \%$ and we accept the alternative hypothesis (reject $\mathrm{H}_{0}$ ) if the $\mathrm{p}$-value is less than $10 \%$. Statistics in table 2 show that all series are of order one and therefore stationary in first difference.

Table2: Panel unit root analysis

\begin{tabular}{|c|c|c|c|c|}
\hline Variable & \multicolumn{2}{|c|}{ Levin-Lin-Chu (LLC) } & \multicolumn{2}{|c|}{ Im-Pesaran-Shin (IPS) } \\
\hline & At Level & First difference & At Level & First difference \\
\hline $\ln Y_{t}$ & $\begin{array}{c}-3.2256 \\
(0.2135)\end{array}$ & $\begin{array}{c}-5.5689 \\
(0.0032)^{\star \star \star}\end{array}$ & $\begin{array}{l}-2.6248 \\
(0.5020)\end{array}$ & $\begin{array}{c}-2.3628 \\
(0.0232)^{* *}\end{array}$ \\
\hline $\ln F D I_{t}$ & $\begin{array}{l}-2.2248 \\
(0.2071)\end{array}$ & $\begin{array}{c}-3.7481 \\
(0.0146)^{\star *}\end{array}$ & $\begin{array}{c}-3.3158 \\
(0.44310)\end{array}$ & $\begin{array}{c}-5.0014 \\
(0.0018)\end{array}$ \\
\hline $\ln T S_{t}$ & $\begin{array}{l}-4.1489 \\
(0.1072)\end{array}$ & $\begin{array}{c}-8.8452 \\
(0.0000)^{\star * \star}\end{array}$ & $\begin{array}{l}-3.3248 \\
(0.4511)\end{array}$ & $\begin{array}{c}-4.6241 \\
(0.0024)^{* * *}\end{array}$ \\
\hline $\ln D I_{t}$ & $\begin{array}{l}-4.4787 \\
(0.1001)\end{array}$ & $\begin{array}{c}-7.1114 \\
(0.0000)^{\star \star *}\end{array}$ & $\begin{array}{l}-5.3800 \\
(0.1442)\end{array}$ & $\begin{array}{l}-5.14474 \\
(0.0011)^{\star \star \star}\end{array}$ \\
\hline
\end{tabular}




\begin{tabular}{|c|c|c|c|c|}
\hline $\ln T O_{t}$ & $\begin{array}{c}-4.1485 \\
(0.1615) \\
\end{array}$ & $\begin{array}{c}-6.6597 \\
(0.0000)^{* \star *}\end{array}$ & $\begin{array}{c}-4.5487 \\
(0.1720) \\
\end{array}$ & $\begin{array}{c}-6.6248 \\
(0.0000)^{* * *}\end{array}$ \\
\hline $\ln E_{t}$ & $\begin{array}{l}-5.1482 \\
(0.1027)\end{array}$ & $\begin{array}{c}-7.2635 \\
(0.0000)^{\star \star \star}\end{array}$ & $\begin{array}{c}-0.8001 \\
(0.6280) \\
\end{array}$ & $\begin{array}{c}-4.6148 \\
(0.0023)^{* * *}\end{array}$ \\
\hline $\ln U_{t}$ & $\begin{array}{l}-3.6899 \\
(0.1751) \\
\end{array}$ & $\begin{array}{c}-5.4177 \\
(0.0030)^{* \star \star}\end{array}$ & $\begin{array}{c}-0.7004 \\
(0.6552) \\
\end{array}$ & $\begin{array}{c}-6.9875 \\
(0.0000)^{* * *}\end{array}$ \\
\hline $\ln F D_{t}$ & $\begin{array}{c}-1.5011 \\
(0.3471)\end{array}$ & $\begin{array}{c}-5.7025 \\
(0.0037)^{* * *}\end{array}$ & $\begin{array}{c}-5.6895 \\
(0.1413)\end{array}$ & $\begin{array}{c}-6.5814 \\
(0.0000)^{* * *}\end{array}$ \\
\hline $\ln K_{t}$ & $\begin{array}{c}-2.6001 \\
(0.3238) \\
\end{array}$ & $\begin{array}{c}-4.7887 \\
(0.0038)^{* * *}\end{array}$ & $\begin{array}{c}-1.7488 \\
(0.6120) \\
\end{array}$ & $\begin{array}{c}-4.7003 \\
(0.0021)^{* * *}\end{array}$ \\
\hline $\ln H K_{t}$ & $\begin{array}{l}-3.1414 \\
(0.2004)\end{array}$ & $\begin{array}{c}-6.2650 \\
(0.0000)^{* * *}\end{array}$ & $\begin{array}{l}-4.2400 \\
(0.1640)\end{array}$ & $\begin{array}{c}-2.4111 \\
(0.0166)\end{array}$ \\
\hline
\end{tabular}

The next step is to test whether there is a long-run equilibrium relationship between these variables. We use the co-integration test of Pedroni (2004) formed by seven co-integration tests on data from both homogeneous and heterogeneous panels. The results of Pedroni's (2004) test reported in Table 3 confirm the rejection of the null hypothesis of no cointegration. Based on the $p$-values, we conclude that economic growth and its determinants are co-integrated in the long-run. In fact, the results of both within and between dimensions statistics show that the alternative hypothesis of co-integration should be accepted for the three sub-panels along with the global panel. Based on these findings, we conclude that endogenous and exogenous variables do have a long-term relationship to all panels.

Table 3: Pedroni Cointegration Test

\begin{tabular}{|c|c|c|c|c|}
\hline & \multicolumn{2}{|c|}{ High-income panel } & \multicolumn{2}{|c|}{ Middle-income panel } \\
\hline \multicolumn{5}{|c|}{ Tests between Dimensions } \\
\hline & Statistics & P-value & Statistics & P-value \\
\hline V-stat & $-4,0846$ & $(0,0031)^{\star * *}$ & $-2,1351$ & $0,0253^{\star *}$ \\
\hline Rho-stat & $-4,0833$ & $0,0030^{* * \star}$ & $-3,0934$ & $0,0134^{\star *}$ \\
\hline Pp-stat & $-5,096$ & $0,0000^{* * *}$ & $-3,0945$ & $0,0131^{* *}$ \\
\hline Adf-stat & $-4,9071$ & $0,0005^{\star * *}$ & $-5,3889$ & $0,0000^{* * *}$ \\
\hline \multicolumn{5}{|c|}{ Tests within Dimensions } \\
\hline Rho-stat & $-3,4474$ & $0,0114^{\star \star}$ & $-4,7161$ & $0,0011^{*}$ \\
\hline Pp-stat & $-5,1052$ & $0,0000^{*}$ & $-5,4003$ & $0,0000^{*}$ \\
\hline \multirow[t]{2}{*}{ Adf-stat } & $-6,4915$ & $0,0000^{*}$ & $-2,9612$ & $0,0220^{\star *}$ \\
\hline & \multicolumn{2}{|c|}{ Low-income panel } & \multicolumn{2}{|c|}{ Global panel } \\
\hline \multicolumn{5}{|c|}{ Tests between Dimensions } \\
\hline $\begin{array}{l}\text { Tests between } \\
\text { Dimensions }\end{array}$ & Statistics & P-value & Statistics & P-value \\
\hline V-stat & $-6,6536$ & $0,0000^{* * *}$ & $-4,1246$ & $0,0029^{* \star \star}$ \\
\hline Rho-stat & $-3,4523$ & $0,0112^{\star *}$ & $-5,4283$ & $0,0000^{* * *}$ \\
\hline Pp-stat & $-3,6122$ & $0,0105^{\star *}$ & $-5,4353$ & $0,0000^{* * *}$ \\
\hline Adf-stat & $-4,8353$ & $0,0008^{* * *}$ & $-6,0276$ & $0,0000^{* * *}$ \\
\hline \multicolumn{5}{|c|}{ Tests within Dimensions } \\
\hline Rho-stat & $-5,0751$ & $0,0000^{*}$ & $-2,4102$ & $0,0232^{* *}$ \\
\hline Pp-stat & $-4,5072$ & $0,0017^{*}$ & $-3,7041$ & $0,0143^{* *}$ \\
\hline Adf-stat & $-4,3252$ & $0,0021^{*}$ & $-3,1654$ & $0,0135^{\star *}$ \\
\hline
\end{tabular}


Note: Panel cointegration tests include intercept; ${ }^{* \star *},{ }^{* *}$ significant at $1 \%$ and $5 \%$ levels respectively,

The results of the global panel are recorded in Table 4 below. The DI has coefficient of 0.159 indicating positive impact on economic growth. We note that $1 \%$ increase in DI leads to enhance economic growth by $0.159 \%$. The results confirm the findings of Qiang (2009) for 120 developing countries who indicate that increase a $10 \%$ of the information communication technology adoption rate has resulted in an increase of $0.8 \%$ of economic growth in middle income countries. The TS affects positively and significantly the economic growth. A magnitude of 0.221 implies that if TS increases by $1 \%$, the economic growth augment by $0.221 \%$. Theoretically, the positive impact of transportation is very supported and confirmed by Samir et al, 2020 for 46 developing countries; Khadaroo and Seetanah (2008) for Muritius.

In addition, the human capital affects positively the economic growth at $1 \%$ level. Our results confirm the ones of importantly, we find that trade openness and capital stock have positive effects on economic growth at $1 \%$ level. Moreover, the statistics of Model 2 present the influence of explanatory variables on the variation of transportation services. In fact, we found a positive impact for economic growth, FDI, capitalstock. An increase by $1 \%$ in these variables gives a development on the transportation services by $0.313 \% ; 0.168 \% ; 0.192 \%$ respectively. For the energy, urbanization, the impact on transportation services is positive at different level of significance. However, the transportation services not affect by digital infrastructures in a significant way. Finally, in Model 3, we found that DI depends on economic growth at $1 \%$ level. A high coefficient confirms strongly the positive link between economic growth and digital infrastructures. These results are in line with those of Oulton (2012) for the United Kingdom; Daveri (2002) for economies of European Union; Kumar and Kumar (2012) for Fiji; Kuppusamy et al. (2009) for Malaysia.

The same positive impact is also detected for transportation services, urbanization, capital stock and human capital in different level of signification.

For the high-income countries (HI), Model 1 summarizes the impact of different factors on economic growth. First, the impact of FDI is found positive since a development of FDI stock by $1 \%$ tends to increase the economic growth by $0,278 \%$. The transportation service has also a strong effect on economic growth. A coefficient of 0,324implies that the economic growth augments by $0,324 \%$ when the transportation service increases by $1 \%$. The same positive impact is detected for the DI, trade openness, capital stock and human capital.

Model 2 seems to show how different factors affect transportation services in $\mathrm{HI}$ countries. A positive impact at the $1 \%$ level of significance is attributed to the economic growth, FDI, energy consumption and urbanization. The development of these variables by $1 \%$ leads to enhance the transportation services by $0,244 \% ; 0,324 \% ; 0,358 \% ; 0,317 \%$, respectively. Concerning the DI and capital stock the impact ispositive at $5 \%$ level.

The statistics of Model 3confirm a direct impact of economic growth on the digital infrastructures which increase by $0,308 \%$ if there is an economic development by $1 \%$. Also, we found a positive relationship between transportation services and digital infrastructures. The coefficient of 0,163 indicates that a $1 \%$ augmentation in transportation services tends to develop the digital infrastructures by $0,163 \%$. Moreover, the development of urbanization by $1 \%$ leads to rise digital infrastructures by $0,262 \%$. Furthermore, the results show that both capital stock and human capital have a direct and positive influence on the digital infrastructures. The statistics of 0,188 and 0,199 demonstrate that these infrastructures may augment by $0,188 \%$ and $0,199 \%$ if the capital and human capital augment by $1 \%$, respectively. However, we do not find a significant relationship between FD and DI for the HI countries. 
For the panel of middle-income countries, the statistics of Model 1 show that the economic growth depends positively on the attractiveness of FDI, transport, and DI. A coefficient of 0,253 indicates that the economic growth in middle income countries grows by $0.253 \%$ if the stock of FDI augments by $1 \%$. Similarly, the magnitude of 0,264 and 0,123 imply that $1 \%$ increase in the transport and digital infrastructure causes the augmentation of economic growth by $0.264 \%$ and $0.123 \%$, respectively. Moreover, the development of trade openness by $1 \%$ leads to rise the economic growth by $0,363 \%$. Furthermore, we found that the human capital and capital stock have positive effects on the economic growth in the middle-incomes countries.

Model 2 presents the influence of explanatory variables on the variation of transportation services in the countries of the second panel. In fact, we found a positive impact for the economic growth, FDI inflows, and DI. An increase by $1 \%$ in these variables gives a development on the transportationservices by $0,324 \%, 0,182 \%$, and $0,034 \%$, respectively. For the energy use, urbanization and capital stock the contribution on transport services is positive at different level of significance. Finally, in Model 3, we found that the digital infrastructures in the middle-incomes countries depend on economic growth at the $1 \%$ level. Indeed, an augmentation by $1 \%$ on the economic growth gives an increase in the digital infrastructures by $0,293 \%$. The same positive impact is also detected for the transportation services and urbanization. A magnitude of 0,292 and 0,229 implies that the digital infrastructures increase by $0.292 \%$ and $0.229 \%$ if the transportation service and urbanization increase by $1 \%$ respectively. Concerning the influence of capital and human capital, the findingsprove a positive impact at the level of $1 \%$ for the capital and at the level of $5 \%$ for the human capital. In contrast, the FD has no significant impact on digital infrastructures in middle incomes countries.

Concerning the panel of low-income countries, the statistics of Model 1 follow the same trend as the first panel. The results demonstrate that the economic growth depends positively to FDI attractiveness, transport, DI, TO, capital and human capital in different level of significance. By Model 2, we estimate the coefficients of the explanatory variables on transportation services. We found that the economic growth affects positively the development of transportation services in the low-income countries. Indeed, a coefficient of 0,352 indicates that the augmentationby $1 \%$ of the economy allows the increase of the transportation services by $0,352 \%$.

In the same way, the impact of FDI and energy demand is found positive and statistically significant. The transport services increase by $0,165 \%$ and $0,328 \%$ if there is an augmentation by $1 \%$ of the FDI inflows and energy demand respectively. The positive relationship between urbanization and transport services is clearly proved by the magnitude of 0,215 . Indeed, a $1 \%$ increase in the urbanization in the low incomepanel implies a development of transportation services by $0,215 \%$. For the remaining explanatory variables, we found a positive impact at the $1 \%$ level of significance for the capital stock at the $5 \%$ level. Compared to middle income panel, we found that the influence of digital infrastructures is not important to impact transportation services.

Finally, Model 3 confirms the positive impact of economic growth and transportation service on the development of digital infrastructures. The economic growth has a positive coefficient implying that these infrastructures grow by $0,317 \%$, if there is an economic development by $1 \%$. Also, the coefficient of 0,1506 imply that the digital infrastructures increase by $0,150 \%$ if the transport services increase by $1 \%$. Moreover, the results indicate that the digital infrastructure is positively affected by urbanization, FD, capital stock, and human capital. We can note that in spite middle income countries, FD has a significant impact on DI in low income countries. 
Oradea Journal of Business and Economics, Volume VI, Issue 2

Published in September 2021

Table 4: Empirical results

\begin{tabular}{|c|c|c|c|c|c|c|c|c|c|c|c|c|}
\hline \multirow[b]{2}{*}{ HIC } & \multicolumn{3}{|c|}{62 countries } & \multicolumn{3}{|c|}{ High-income countries } & \multicolumn{3}{|c|}{ Middle-income countries } & \multicolumn{3}{|c|}{ Low-income countries } \\
\hline & Model 1 & Model 2 & Model 3 & Model 1 & Model 2 & Model 3 & Model 1 & Model 2 & Model 3 & Model 1 & Model 2 & Model 3 \\
\hline $\begin{array}{c}\text { Independent } \\
\text { variables }\end{array}$ & & & & GDPC & TS & DI & GDPC & TS & DI & GDPC & TS & DI \\
\hline $\ln Y_{t}$ & & $\begin{array}{c}0,3137 \\
(0.0000)^{* * *}\end{array}$ & $\begin{array}{c}0,3019 \\
(0.0000)^{* * *}\end{array}$ & & $\begin{array}{c}0,2445 \\
(0,001)^{* * *}\end{array}$ & $\begin{array}{c}0,3086 \\
(0,0000)^{* * *}\end{array}$ & & $\begin{array}{c}0,3244 \\
(0,0000)^{* * *}\end{array}$ & $\begin{array}{c}0,2934 \\
(0,000)^{* * *}\end{array}$ & & $\begin{array}{c}0,3529 \\
(0,0000)^{* * *}\end{array}$ & $\begin{array}{c}0,3170 \\
(0,0000)^{* * *}\end{array}$ \\
\hline $\ln F D I_{t}$ & $\begin{array}{c}0,2719 \\
(0.0000)^{* * *}\end{array}$ & $\begin{array}{c}0,1682 \\
(0.0414)^{* *}\end{array}$ & & $\begin{array}{l}0,2781 \\
(0,000)^{*+*}\end{array}$ & $\begin{array}{l}0,3247 \\
(0,000)^{*+*}\end{array}$ & & $\begin{array}{c}0,2535 \\
(0,0219)^{\star *}\end{array}$ & $\begin{array}{c}0,1827 \\
(0,0478)^{* *}\end{array}$ & & $\begin{array}{c}0,3269 \\
(0,0000)^{*+* *}\end{array}$ & $\begin{array}{c}0,1650 \\
(0,0252)^{* *}\end{array}$ & \\
\hline $\ln T S_{t}$ & $\begin{array}{c}0,2215 \\
(0.0018)^{* * *}\end{array}$ & & $\begin{array}{c}0,3008 \\
(0.0000)^{* * *}\end{array}$ & $\begin{array}{c}0,3247 \\
(0,000)^{* * *}\end{array}$ & & $\begin{array}{c}0,1631 \\
(0,0313)\end{array}$ & $\begin{array}{c}0,2644 \\
(0,0210)\end{array}$ & & $\begin{array}{c}0,2924 \\
(0,0115)\end{array}$ & $\begin{array}{c}0,2502 \\
(0,0016)^{* * *}\end{array}$ & & $\begin{array}{c}0,1506 \\
(0,0283)^{* *}\end{array}$ \\
\hline $\ln D I_{t}$ & $\begin{array}{c}0,1597 \\
(0.0429)^{* *}\end{array}$ & $\begin{array}{c}0,0229 \\
(0.2348)\end{array}$ & & $\begin{array}{c}0,1980 \\
(0,0201)^{* *}\end{array}$ & $\begin{array}{c}0,1536 \\
(0.0307)\end{array}$ & & $\begin{array}{c}0,1235 \\
(0,0515)\end{array}$ & $\begin{array}{c}0,0344 \\
(0,0810)^{*}\end{array}$ & & $\begin{array}{c}0,1373 \\
(0,0401)^{* *}\end{array}$ & $\begin{array}{c}0,0177 \\
(0,2263)\end{array}$ & \\
\hline $\ln T O_{t}$ & $\begin{array}{c}0,3193 \\
(0.0000)^{* * *}\end{array}$ & & & $\begin{array}{c}0,1504 \\
(0,039)^{* * *}\end{array}$ & & & $\begin{array}{c}0,3634 \\
(0,0000)^{* * *}\end{array}$ & & & $\begin{array}{c}0,3249 \\
(0,0000)^{* * *}\end{array}$ & & \\
\hline $\ln E_{t}$ & & $\begin{array}{c}0,3583 \\
(0,0000)^{* * *}\end{array}$ & & & $\begin{array}{c}0,3583 \\
(0,0000)\end{array}$ & & & $\begin{array}{c}0,3076 \\
(0,0000)^{* * *}\end{array}$ & & & $\begin{array}{c}0,3289 \\
(0,0000)^{* * *}\end{array}$ & \\
\hline $\ln U_{t}$ & & $\begin{array}{c}0,3171 \\
(0,0000)^{* * *} \\
\end{array}$ & $\begin{array}{c}0,2628 \\
(0,0017)^{* * *}\end{array}$ & & $\begin{array}{c}0,3171 \\
(0,0000)^{* * *}\end{array}$ & $\begin{array}{c}0,2628 \\
(0,0017)^{* * *}\end{array}$ & & $\begin{array}{c}0,3267 \\
(0,0000)^{* * * *}\end{array}$ & $\begin{array}{c}0,2296 \\
(0,0244)^{* *}\end{array}$ & & $\begin{array}{c}0,2155 \\
(0,0051)^{* * *}\end{array}$ & $\begin{array}{r}0,1267 \\
(0,0420)\end{array}$ \\
\hline $\ln F D_{t}$ & & & $\begin{array}{l}0,0994 \\
(0,352) \\
\end{array}$ & & & $\begin{array}{l}0,0994 \\
(0,352) \\
\end{array}$ & & & $\begin{array}{l}0,0165 \\
(0,260) \\
\end{array}$ & & & $\begin{array}{r}0,0905 \\
(0,0662)\end{array}$ \\
\hline $\ln K_{t}$ & $\begin{array}{l}0,15048 \\
(0,039)^{* *}\end{array}$ & $\begin{array}{c}0,1013 \\
(0,0401)^{* *}\end{array}$ & $\begin{array}{c}0,1882 \\
(0,0262)^{* *}\end{array}$ & $\begin{array}{l}0,15048 \\
(0,039)^{* *}\end{array}$ & $\begin{array}{c}0,1013 \\
(0,0401)^{* *}\end{array}$ & $\begin{array}{c}0,1882 \\
(0,0262)\end{array}$ & $\begin{array}{c}0,2626 \\
(0,0212)^{* *}\end{array}$ & $\begin{array}{c}0,3129 \\
(0,0000)^{* * *}\end{array}$ & $\begin{array}{c}0,3014 \\
(0,0000)^{* * *}\end{array}$ & $\begin{array}{c}0,2343 \\
(0,0031)^{* * *}\end{array}$ & $\begin{array}{c}0,2107 \\
(0,0052)^{* * *}\end{array}$ & $\begin{array}{c}0,1017 \\
(0,0540)^{*}\end{array}$ \\
\hline $\ln H K_{t}$ & $\begin{array}{c}0,3247 \\
(0,000)^{* * *}\end{array}$ & & $\begin{array}{c}0,1993 \\
(0,0200)^{* *}\end{array}$ & $\begin{array}{c}0,3247 \\
(0,000)^{* * *}\end{array}$ & & $\begin{array}{c}0,1993 \\
(0,0200)\end{array}$ & $\begin{array}{c}0,1992 \\
(0,0353)\end{array}$ & & $\begin{array}{c}0,2021 \\
(0,0300)^{* *}\end{array}$ & $\begin{array}{c}0,2725 \\
(0,0032)^{*+*}\end{array}$ & & $\begin{array}{c}0,2246 \\
(0,0044)^{* *}\end{array}$ \\
\hline Constant & $\begin{array}{c}1,3186 \\
(0,001)^{* * *}\end{array}$ & $\begin{array}{c}0,2227 \\
(0,041)^{* *}\end{array}$ & $\begin{array}{c}0,2445 \\
(0,048)^{* *}\end{array}$ & $\begin{array}{l}1,3186 \\
(0,001)^{* * *}\end{array}$ & $\begin{array}{c}0,2227 \\
(0,041)^{* *}\end{array}$ & $\begin{array}{c}0,2445 \\
(0,048)^{* *}\end{array}$ & $\begin{array}{c}1,3186 \\
(0,001)^{* * *}\end{array}$ & $\begin{array}{c}0,2227 \\
(0,041)^{* *}\end{array}$ & $\begin{array}{l}0,2445 \\
(0,048)\end{array}$ & $\begin{array}{c}1,3053 \\
(0,001)^{* * *}\end{array}$ & $\begin{array}{l}0,2205 \\
(0,041)^{* *}\end{array}$ & $\begin{array}{c}0,2420 \\
(0,048)^{* *}\end{array}$ \\
\hline $\begin{array}{l}\text { Hansen J-test } \\
\text { (p-value) }\end{array}$ & $\begin{array}{l}22,077 \\
(0,115)\end{array}$ & $\begin{array}{l}16,3825 \\
(0,225)\end{array}$ & $\begin{array}{c}14,7213 \\
(0,325)\end{array}$ & $\begin{array}{l}22,077 \\
(0,115)\end{array}$ & $\begin{array}{c}16,3825 \\
(0,225)\end{array}$ & $\begin{array}{c}14,7213 \\
(0,325)\end{array}$ & $\begin{array}{l}22,077 \\
(0,115)\end{array}$ & $\begin{array}{c}16,3825 \\
(0,225)\end{array}$ & $\begin{array}{l}14,7213 \\
(0,325)\end{array}$ & $\begin{array}{l}21,854 \\
(0,115)\end{array}$ & $\begin{array}{c}16,2170 \\
(0,225)\end{array}$ & $\begin{array}{c}14,5726 \\
(0,325)\end{array}$ \\
\hline $\begin{array}{l}\text { AR2 test } \\
\text { (p-value) }\end{array}$ & & & & $\begin{array}{l}0,0623 \\
(0,950)\end{array}$ & $\begin{array}{l}0.1465 \\
(0.684)\end{array}$ & $\begin{array}{c}0.244 \\
(0.847)\end{array}$ & $\begin{array}{c}0,06237 \\
(0,950)\end{array}$ & $\begin{array}{l}0,1465 \\
(0,684)\end{array}$ & $\begin{array}{c}0,24453 \\
(0,847)\end{array}$ & $\begin{array}{l}0,0617 \\
(0,950)\end{array}$ & $\begin{array}{l}0,3529 \\
(0,684)\end{array}$ & $\begin{array}{l}0,3170 \\
(0,847)\end{array}$ \\
\hline
\end{tabular}




\section{Conclusion}

This study has investigated the linkages between economic development, transportation services, and digital infrastructures in 62 countries from 2000 to 2018 (during the amount of 19 years). The relationships between the variables are estimated by applying the GMM estimator. The empirical results show a bidirectional relationship between economic development, digital infrastructures and transportation services for all panels. The economic development contains a positive impact on transportation services and digital infrastructures for the high-income, middle income, and low-income countries. Furthermore, the results show that the connection between transportation services and digital infrastructures is bidirectional for the middle and high-income panels and unidirectional, from transportation services to digital infrastructures, for the low-income countries panel.

Importantly, developing countries could take various measures to adopt new strategies to reinforce their competitiveness in terms of digital infrastructure. For this reason, the government could also implement programmers that increase the provision of digital infrastructures, which could facilitate learning and other activities. Consequently, the connection between human capital and digital infrastructure allows several countries to draw in new talents and improve the citizen's competences. Therefore, investment in human capital is a vital policy consideration to boost the expansion effects of digital infrastructures. Besides, digital infrastructures promote science and research and stimulate innovation, productivity, employment and growth. Moreover, the positive and significant impact of digital infrastructures on transportation services shows that the event of digital infrastructures will be useful for the countries' economies especially for the foreign companies. Furthermore, this observation confirms that countries can augment the transportation services if they augment their investments on digital infrastructures. It is to be noted that digital infrastructures can facilitate cross-border communication, financial transactions and might also play a catalytic role in regional integration and trade facilitation particularly by reducing time frames and costs.

In the same context, these findings recommend, to encourage and support the investment of digital infrastructure which is useful for countries to play positive role in upgrading the economic sector and have in generating the creation of latest opportunities to reinforce production processes. In others words, digital infrastructures is the most crucial driver to boost transport, trade and financial development. As a final point, it is to be mentioned that our findings may be enhanced by considering the strong relationship between DI, TS and economic growth and by examining their impact on other variables such as heath expenditure, intelligent transport within the industry 4.0 erea.

\section{References}

Achour, H., Belloumi, M. 2016. Investigating the causal relationship between transport infrastructure, transport energy consumption and economic growth in Tunisia. Renewable and Sustainable Energy Reviews, 56(C), pp. 988-998.http://doi.10.1016/j.rser.2015.12.02 Adedoyin, F.F., Bekun, F.V., Driha, O.M, and Balsalobre-Lorente, D. 2020. The effects of air transportation, energy, ICT and FDI on economic growth in the industry 4.0 era: Evidence from the United States. Technological Forecasting \& Social Change, 160. http://doi.org/10.1016/j.techfore.2020.120297

Aleksandra, S., Joan T.S. 2017. ICT, Innovation and Productivity: Evidence Based on Eastern European Manufacturing Companies. Journal of the Knowledge Economy, 8(2), pp. 768-788.http://doi.10.1007/s13132-016-0441-1 
Arellano, M., Bond, S.R.1991. Some tests of specification for panel data: Monte Carlo evidence and an application to employment equations. The Review of Economic Studies, 58(2), pp. 277-297. http://doi.org/10.2307/2297968

Cardona, M., Kretschmer, T., and Strobel, T. 2013. ICT and productivity: conclusions from the empirical literature. Information Economics and Policy, 25 (3), pp. 109125https://doi.org/10.1016/i.infoecopol.2012.12.002

Chi, J., 2016. Exchange rate and transport cost sensitivities of bilateral freight flows between the US and China. Transportation Research Part A: Policy and Practice, 89, pp. 1-13. http://doi.org/10.1016/j.tra.2016.05.004

Crowley, A.G., 1998. Virtual logistics: transport in the market space. International Journal of Physical Distribution \& Logistics Management, 28(7), pp. 547-574. https://doi.org/10.1108/09600039810247470

Daveri, F., 2002.The new economy in Europe, 1992-2001. Oxford Review of Economic Policy, 18(3), pp. 345-362.https://www.jstor.org/stable/23606592

Hong, J., 2007. Transport and the location of foreign logistics firms: The Chinese experience.

Transportation Research Part A: Policy and Practice, 41(6), pp. 597-609. http://doi.org/10.1016/j.tra.2006.11.004.

Im, K. S., Pesaran,M. H., and Shin, Y., 2003. Testing for unit roots in heterogeneous panels. Journal of Econometrics, 115(1), pp. 53-74.https://doi.org/10.1016/S0304-4076(03)000927.

Jorgenson, D.W., Vu, K., 2007. Information technology and the world growth resurgence. GermanEconomicReview, $\quad$ 8(2), $\quad$ pp.125-145.https://doi.org/10.1111/i.14680475.2007.00401.x

Jorgenson, D.W., Vu, K.M., 2016. The ICT revolution, world economic growth, and policy issues. Telecommunication Policy, 40(5), pp.383-397. https://doi.org/10.1016/j.telpol.2016.01.002

Khadaroo, A.J., Seetanah, B., 2008. Transport infrastructure and foreign direct investment. Journal of International Development, 22, pp.103-123. https://doi.org/10.1002/jid.1506

Kumar, R.R., Kumar, R., 2012. Exploring the nexus between information and communications technology, tourism and growth in Fiji. Tourism Economics, 18(2), pp.359371.https://doi.org/10.5367/te.2012.0117

Kuppusamy, M., Raman, M., and Lee, G., 2009. Whose ICT investment matters to economic growth: private or public?. The Malaysian perspective. The Electronic Journal of Information Systems in Developing Countries, 37(7), pp.1-19.https://doi.org/10.1002/j.16814835.2009.tb00262.x

Lean, H.H., Huang, W., and Hong, J., 2014. Logistics and economic development: Experience from China. Transport Policy, 32, pp.96-104. http://doi.org/10.1016/i.tranpol.2014.01.003

Lee, II Houng and Khatri, Yougesh.Information Technology and Productivity Growth in Asia, 2003. International Monetary Fund, Working Paper No. 03/15,http://ssrn.com/abstract $=879090$

Levin, A., Lin, C. F., and Chu, C. S. J., 2002. Unit root test in panel data: Asymptotic and finite sample properties. Journal of Econometrics, 108(1), pp.1-24. https://doi.org/10.1016/S0304-4076(01)00098-7

Marazzo, M., Scherre, R., and Fernandes, E., 2010. Air transport demand and economic growth in Brazil: a time series analysis. Transportation Research Part E: Logistics and Transportation Review, 46(2),pp.261-269. https://doi.org/10.1016/i.tre.2009.08.008

Mbarek, M.B., Zghidi, N., 2017. Dynamic links between ICT, transport energy, environmental degradation and growth: empirical evidence from Tunisia. Environmental Economics, 8(3), 76-83. DOI:10.21511/ee.08(3).2017.08. 
Niebel, T., 2018. ICT and economic growth -comparing developing, emerging and developed countries. World Development, 104, pp.197-211. https://doi.org/10.1016/i. worlddev.2017.11.024.

Omri, A.,Kahouli, B., 2014. Causal relationships between energy consumption, foreign direct investment and economic growth: Fresh evidence from dynamic simulateous-equations models. Energy Policy ,67, pp.913-922. http://doi.10.1016/i.enpol.2013.11.067

Omri, A., Daly, S.,Rault, C., andChaibi, A.2015. Financial development, environmental quality, trade and economic growth: What causes what in MENA countries. Energy Economics. 48 (C), pp. 242-252. http://doi.10.1016/j.eneco.2015.01.008

Oulton, N., 2012. Long term implications of the ICT revolution: applying the lessons of growth theory and growth accounting. Economic Modelling. 29(5), pp. 1722-1736. https://doi.org/10.1016/j.econmod.2012.04.02

Park, J.S., Seo, Y.J., 2016. The impact of seaports on the regional economies in South Korea: Panel evidence from the augmented Solow model. Transportation Research Part E: Logistics Transportation Review, 85, pp. 107-119. https://dx.doi.org/10.1016/i.tre.2015.11.009

Paunov, C., Rollo, V., 2016. Has the Internet Fostered Inclusive Innovation in the Developing World? World development, 58, 587-609. https://doi.org/10.1016/j.worlddev.2015.10.029

Pedroni, P., 1999. Critical values for cointegration tests in heterogeneous panels with multiple regressors. Oxford Bulletin of Economics and Statistics, 61, pp. 653-670. https://doi.org/10.1111/1468-0084.0610s1653

Pedroni, P., 2004. Panel cointegration: Asymptotic and finite sample properties of pooled time series tests with an application to the PPP hypothesis. Econometric Theory, 20(3), pp. 597-625. http://doi.org/10.1017/S0266466604203073

Pesaran, M.H., 2007. A simple panel unit root test in the presence of cross-section dependence. Journal Of Applied Econometrics, 22, pp. 265-312. http://doi.org/10.1002/jae.951

Roller, L.H., Waverman, L., 2001. Telecommunications infrastructure and economic development: a simultaneous approach. American Economic Review. 95, pp.909-923. http://doi.10.1257/aer.91.4.909

Romer, P., 1990. Endogenous technological change. Journal of Political Economy, 98 (5), S71-S102. https://doi.org/10.3386/w3210

Saidi, S., Hammami, S., 2017. Modeling the causal linkages between transport, economic growth and environmental degradation for 75 countries. Transportation Research Part D: Transport and Environment. 53, pp.415-427. http://doi.10.1016/i.trd.2017.04.031

Saidi, S., Shahbaz, M., and Akhtar, P. 2018. The long-run relationships between transport energy consumption, transport infrastructure, and economic growth in MENA countries. TransportationResearchPart A: Policy and Practice, 111, pp. 78-95. http://doi.1016/i.tra.2018.03.013

Saidi, S., Mefteh, H., 2020. Empirical analysis of the dynamic relationships between transport, ICT and FDI in 63 countries. InternationalEconomic Journal. 34(3), pp.448-471. https://doi.org/10.1080/10168737.2020.1765186

Saidi, S, Mani, V., Mefteh, H., Shahbaz, M., and Akhtar, P., 2020. Dynamic linkages between transport, logistics, foreign direct Investment, and economic growth: Empirical evidence from developing countries. Transportation Research Part A: Policy and Practice. 141, pp. 277293. http://doi.10.1016/j.tra.2020.09.020

Seo, H.J., Lee, Y.S., and Oh, J.H., 2009. Does ICT investment widen the growth gap? Telecommunications Policy, 33(8), pp.422-431. https://doi.org/10.1016/j.telpol.2009.04.001 Shahbaz, M., Zeshan, M., and Tiwari, A.K., 2015. Analysis of renewable and nonrenewable energy consumption, real GDP and CO2 emissions: a structural VAR approach in Romania. 
Bulletin of Energy Economics, 3(3), pp. 105-118. https://mpra.ub.unimuenchen.de/id/eprint/34066

Shan, J., Yu, M., and Lee, C.Y., 2014. An empirical investigation of the seaport's economic impact: Evidence from major ports in China. Transportation Research. Part E: Logistics Transportation Review, 69, pp. 41-53. http://doi.10.1016/i.tre.2014.05.010

Solomon, E.M., Klyton, A., 2020. The impact of digital technology usage on economic growth in Africa. Utilities Policy, 67. https://doi.org/10.1016/i.jup.2020.101104

Sy, A., Tinker, T., Derbali, A., and Jamel, L., 2016. Economic growth, financial development, trade openness, and $\mathrm{CO} 2$ emissions in European countries. African Journal of Accounting, Auditing and Finance, 5(2), pp.155-179. http://doi.10.1504/AJAAF.2016.078320

Venturini, F., 2009. The long-run impact of ICT. Empirical Economics, 37 (3), pp.497-515. https://doi.org/10.1007/s00181-008-0243-9

Vu, K.M., 2013. Information and communication technology (ICT) and Singapore's economic growth. Information Economics and Policy, 25(4), pp.284300.https://doi.org/10.1016/i.infoecopol.2013.08.002

WDI. (2020). https://databank.worldbank.org/source/world-development-indicators

\section{Bionote}

Haifa Mefteh is a higher education assistant at the Institute of Higher Commercial Studies of Sfax. She obtained her doctorate in economics from the University of Sfax in 2015. She has published numerous articles in economics concerning economic development, sustainable development, accumulation of human capital, energy consumption, endogenous growth. 